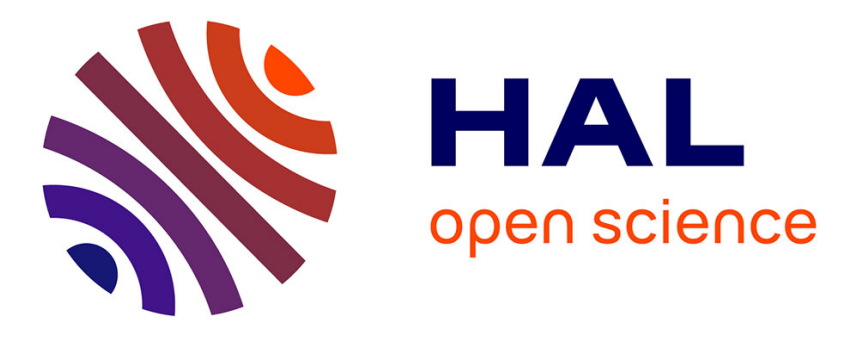

\title{
Interacting Pre-Columbian Amerindian Societies and Environments: Insights from Five Millennia of Archaeological Invertebrate Record on the Saint- Martin Island (French Lesser Antilles)
}

Nathalie Serrand, Dominique Bonnissent

\section{To cite this version:}

Nathalie Serrand, Dominique Bonnissent. Interacting Pre-Columbian Amerindian Societies and Environments: Insights from Five Millennia of Archaeological Invertebrate Record on the SaintMartin Island (French Lesser Antilles). Environmental Archaeology, 2021, 26 (1), pp.99-114. 10.1080/14614103.2018.1450463 . hal-02526948

\section{HAL Id: hal-02526948 \\ https://hal.science/hal-02526948}

Submitted on 5 Apr 2020

HAL is a multi-disciplinary open access archive for the deposit and dissemination of scientific research documents, whether they are published or not. The documents may come from teaching and research institutions in France or abroad, or from public or private research centers.
L'archive ouverte pluridisciplinaire HAL, est destinée au dépôt et à la diffusion de documents scientifiques de niveau recherche, publiés ou non, émanant des établissements d'enseignement et de recherche français ou étrangers, des laboratoires publics ou privés. 


\section{Environmental Archaeology}

The Journal of Human Palaeoecology

\section{Interacting Pre-Columbian Amerindian Societies and Environments: Insights from Five Millennia of Archaeological Invertebrate Record on the Saint- Martin Island (French Lesser Antilles)}

\section{Nathalie Serrand \& Dominique Bonnissent}

To cite this article: Nathalie Serrand \& Dominique Bonnissent (2018): Interacting Pre-Columbian Amerindian Societies and Environments: Insights from Five Millennia of Archaeological Invertebrate Record on the Saint-Martin Island (French Lesser Antilles), Environmental Archaeology

To link to this article: https://doi.org/10.1080/14614103.2018.1450463

曲 Published online: 20 Mar 2018.

Submit your article to this journal $[\pi$

Q View related articles $\asymp$

View Crossmark data $\nearrow$ 


\title{
Interacting Pre-Columbian Amerindian Societies and Environments: Insights from Five Millennia of Archaeological Invertebrate Record on the Saint-Martin Island (French Lesser Antilles)
}

\author{
Nathalie Serrand $\left(\right.$ (i) $^{\mathrm{a}}$ and Dominique Bonnissent ${ }^{\mathrm{b}}$ \\ anstitut national de recherches archéologiques préventives, MR 7209 CNRS MNHN , Guadeloupe-France / UMR 7209 , CNRS MNHN Paris, \\ France; ${ }^{\mathrm{b}}$ Direction des affaires culturelles de Guadeloupe, MInistry of Education and Culture / UMR 8096 CNRS, ARCHAM, France
}

ABSTRACT

Archaeological research, conducted on the French part of Saint-Martin, in the Lesser Antilles, documents the history of Amerindian communities on this island from the 4th millennium $B C$ to the 15 th century AD. Eight sites, spanning almost completely this sequence, have yielded extensive assemblages of invertebrate remains. Analysis and comparison of these assemblages with contemporaneous settlements from nearby islands reveal trends in the ways Amerindian communities exploited these resources. These results, especially when contrasted with a palaeo-climatic frame recently produced for Saint-Martin, reflect the intricate ways in which anthropic and natural systems interact.
ARTICLE HISTORY

Received 10 December 2016 Accepted 5 March 2018

KEYWORDS

Saint-Martin island; archaeomalacology; palaeoclimate; palaeo-environment anthropic/natural systems

\section{Introduction}

Studying past human uses of natural resources offers a prism through which to examine interactions between the systems that human societies create (especially their socio-economic aspects) and various parameters of natural systems (dynamic biotopes and resources) that cultural systems develop in, impact and respond to. Integrated studies of coupled human and natural systems (see Liu et al. 2007) are not yet numerous in the Caribbean, where nevertheless the major issue of past human uses of natural resources has been explored archaeologically from many directions (see e.g. Newsom and Wing 2004).

One investigative line pursued in this paper, comes from assemblages of invertebrate remains (molluscs and crabs) found at eight pre-Columbian settlements excavated on the French part of the island of SaintMartin, in the Lesser Antilles. These sites cover almost completely the known pre-Columbian sequence of this island's Amerindian occupation, from the 4th millennium $\mathrm{BC}$ to the 12th century $\mathrm{AD}$, but do not include the terminal phase of the pre-Columbian period up to the end of the 15th century AD (Figure 1).

The analysis and comparison of the large assemblages of invertebrates coming from these eight sites, as well as of seven other collections from nearby islands and settlements, have produced significant data about Amerindian invertebrate exploitation strategies and their evolution through time. Here, these data are discussed in relation to (1) the known socio-economic characteristics of successive pre-Columbian Amerindian communities in order to elucidate specific trends of these systems, and (2) a recently constructed palaeo-climatic framework for the island of Saint-Martin.

Despite that the human and natural systems are addressed here through incomplete parts - the aspect of invertebrates' exploitation on half an island - and set of data, the perspective offered nevertheless provides interesting leads and trends which obviously are simplified material traces of complex anthropic and natural systems' interacting dynamics. These preliminary projections are discussed here and will need to be further explored, questioned, and refined through larger data bases from various islands.

\section{Environmental and cultural background}

\section{The Lesser Antilles: ecosystems and available resources}

The Caribbean archipelago is composed of more than 7000 islands, islets and cays. They form an arc extending eastward from the Yucatan Peninsula and south from the Florida peninsula. The chain of the smaller islands of the Lesser Antilles, to the east of Puerto Rico, curves southward, terminating in Trinidad, off the northern coast of Venezuela.

Most of the Lesser Antilles islands were formed through subduction processes which resulted in two splitting arcs, north of Dominica. The easternmost is largely composed of extinct volcanoes that have become the core of carbonate reef growth forming low altitude islands. The westernmost archipelago and the southern half of the Lesser Antilles are still active volcanic complexes characterised by mountainous islands. 

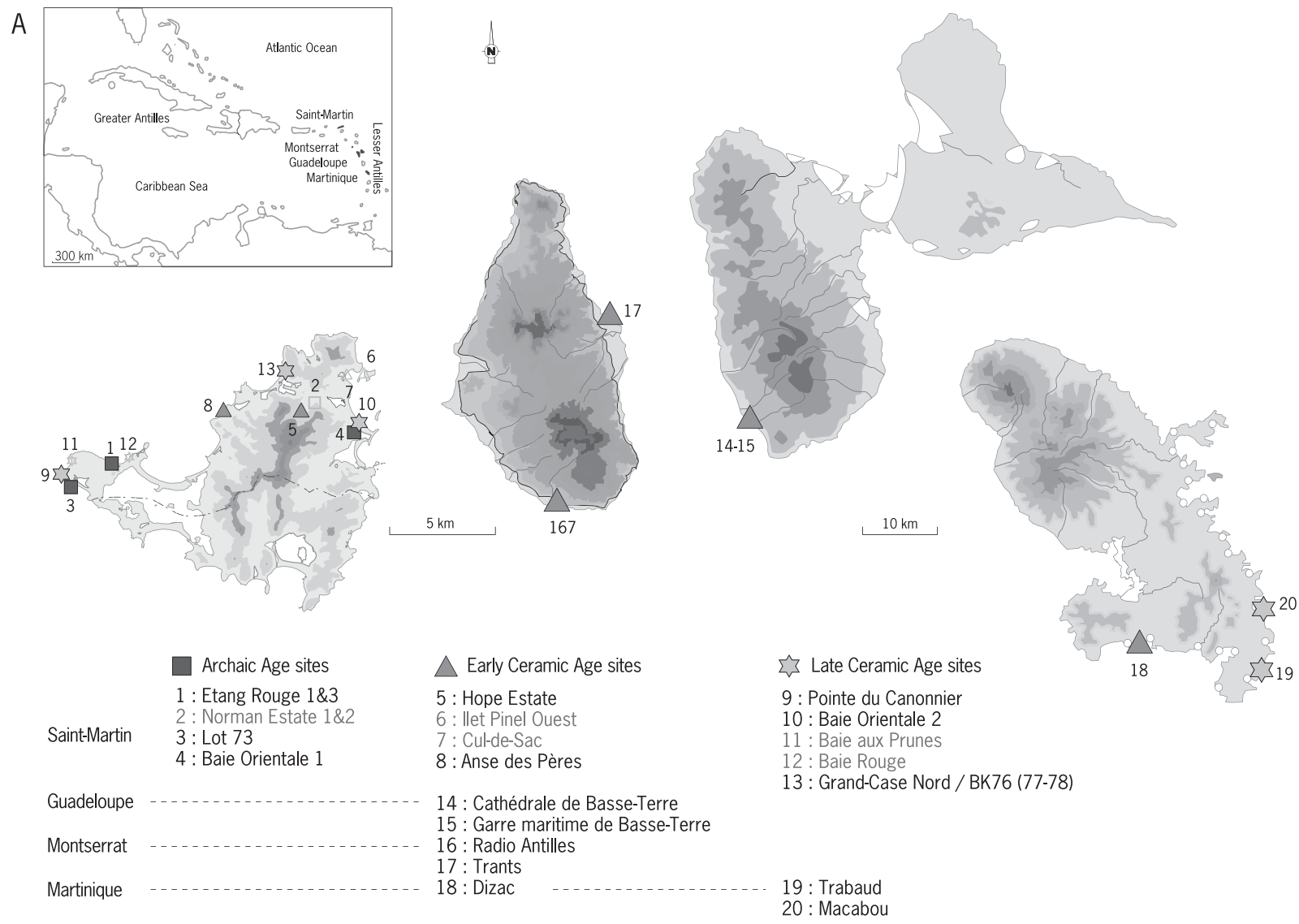

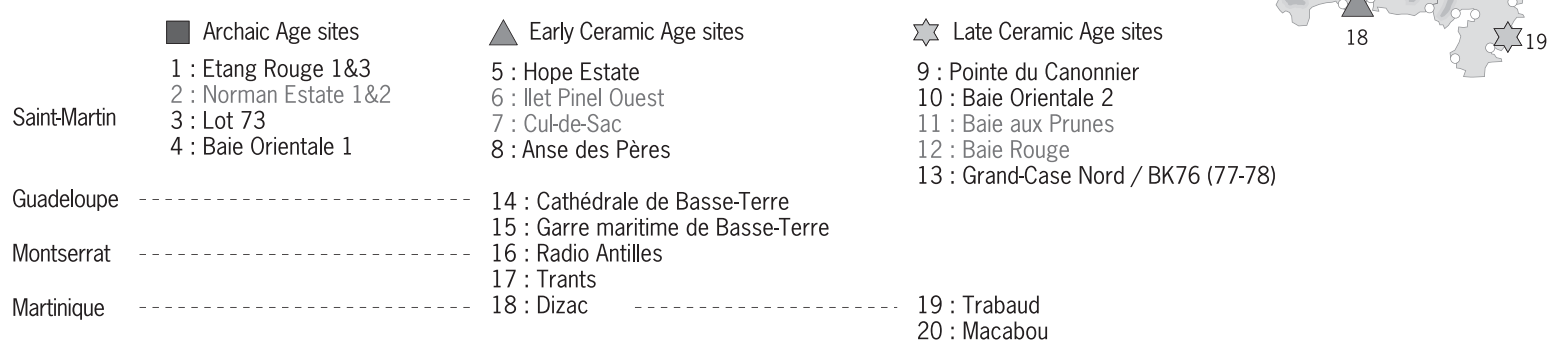

B

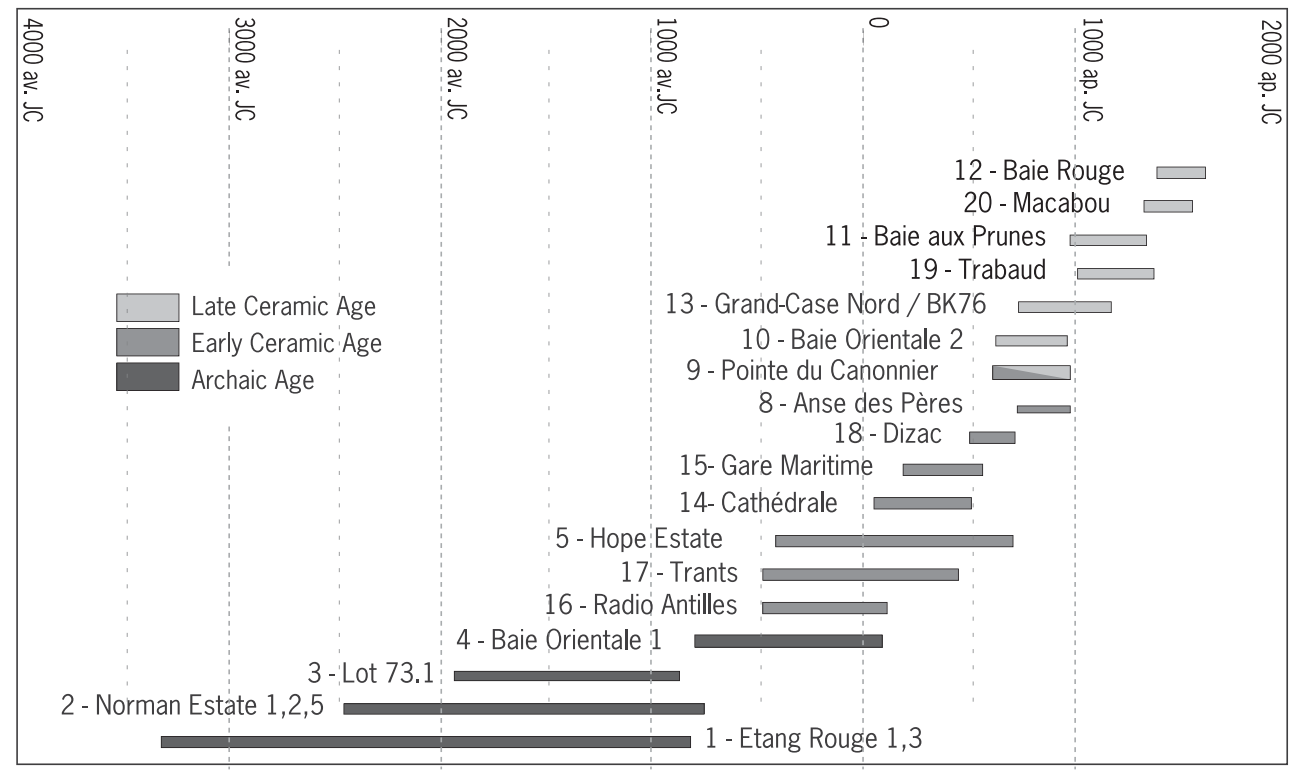

Radiometric dates are in calibrated calendar years (2 sigma, 95\% probability)

The correction of the marine reservoir effect was applied when needed

Figure 1. A. Localisation of the sites used in the study on the maps of Saint-Martin, Montserrat, Guadeloupe and Martinique; B. Chart of the radiometric dates of the sites used in the study. Chart adapted from Bonnissent et al. (2016).

In these tropical to subtropical islands, temperatures (average $24-29^{\circ} \mathrm{C}$ ), humidity and rainfall (annual average $1000-2000 \mathrm{~mm}$ ) vary with elevation, island size and water currents. Warm, moist trade winds blow consistently from the east creating rain forest /semi desert divisions on the mountainous islands. The region has distinct dry and wet seasons, with the latter characterised by hurricane occurrence. The Caribbean
Sea is one of the largest salt water seas, with water temperatures ranging from $22^{\circ} \mathrm{C}$ to $31^{\circ} \mathrm{C}$.

On these islands, especially the smaller ones $\left(<100 \mathrm{~km}^{2}\right)$ such as Saint-Martin, the interaction of these multiple non-static parameters (e.g. geological, geographical, climatic, etc.) produced complex and diverse tropical environmental systems with specific mineral, hydrological, plant, and faunal resources. 
Before the arrival of humans, terrestrial ecosystems lacked big mammals but included small rodents, chiroptera, birds, amphibians, reptiles and land crabs. Native fauna was vulnerable to abrupt changes (Pregill, Steadman, and Watters 1994; Lenoble et al. 2008). Littoral ecosystems, including mangroves, estuaries, and intertidal transitions, were rich with fish, invertebrate and crab communities but exposed to small scale/ short term variations. Finally, more stable marine ecosystems hosted important coral reef formations and large schools of fish, turtles and sea mammals.

These ecosystems and their resources, sometimes unique to an island, evolved in time through highly dynamic processes including alternating wet and dry periods, droughts, sea level changes and various other climatic trends occurring on short and long term scales (Higuera-Gundy 1991; Hodell et al. 1991; Burney, Burney, and MacPhee 1994). The changing biogeography of these 'living islands' was the scene where preColumbian communities settled and developed during at least 6500 years (Keegan 1999; and Boothroyd 2011).

\section{Cultural chronology and subsistence economies}

The initial peopling of the Caribbean archipelago, around ca. 5000 BC (Cuba, Hispaniola, Trinidad), probably occurred as distinct migration pulses originating in different parts of the surrounding continents, including northeastern South America and Central America (Yucatan Peninsula) (Boomert 2000; Rodríguez Ramos, Pagán Jiménez, and Hofman 2013; Fitzpatrick 2015). These first communities developed during several millennia, but, as they are seen through partially preserved sites (due to sea-level transgression), they are not yet fully understood. Lithic and shell tool traditions are observed along with evidence of plant cultivation practices (Pagán-Jiménez et al. 2015), sedentary processes and, in the Greater Antilles, early production of ceramics around 2000 BC (Rodríguez Ramos et al. 2008). Although not satisfactory, the common name of Archaic Age communities will be used here to refer to the populations of that period in the Lesser Antilles.

These communities apparently interacted with newcomers who arrived from the northern coasts of Venezuela, into the Lesser Antilles around 500 BC. These village, horticultural, pottery-making peoples of the Cedrosan-Saladoid subseries migrated as far north as the eastern tip of Hispaniola (Siegel 1991; Rouse 1992; Fitzpatrick 2015). The Early Ceramic Age is characterised by cultural unity and strong cultural interaction with various mainland groups (Boomert 2000). This pattern changes after the onset of the Late Ceramic Age, ca. 600/800 AD, when cultural, sociopolitical, and economic regionalisation occurs (evidenced by the regional development of Ostionoid and Troumassoid ceramic series), along with a growth in the number of sites and colonisation of the remaining unsettled islands of the Lesser and Greater Antilles and the Bahamas. This time of divergent local developments also sees an increase in social complexity but ends with the contact period (Fitzpatrick 2015).

Much has been written on the Caribbean preColumbian subsistence economies and their complex adaptation to local island conditions (see for example Newsom and Wing 2004). Here, invertebrates played an important role as food and raw material, especially in the small islands of the Lesser Antilles. Their importance nonetheless fluctuated through time, probably reflecting economic, cultural, and social processes in human communities, as well as local and large-scale palaeo-environmental dynamics.

\section{Contexts and materials}

The island of Saint-Martin, in the Northern Lesser Antilles, is just $85 \mathrm{~km}^{2}$ (Figure 1A). It was undoubtedly part of a larger geographical and cultural sphere during Amerindian pre-Columbian times (Haviser 1991).

Saint-Martin island offered defined, yet varied, ecosystemic potentials: the hilly central part (highest point: $424 \mathrm{~m}$ ) formerly had dense dry forests; the coastline alternates long sandy beaches, rocky headlands and sandy bars in front of developed lagoon and mangrove areas; and the geology includes some certain desirable stone resources, which were heavily exploited (SaintMartin calcirudite, cherto-tuffite) and exported during Amerindian times (Knippenberg 2006; Stouvenot and Randrianasolo 2006).

Saint-Martin's archaeological occupation is fairly well documented (see Haviser 1988, 1995). Here, we have chosen to focus on data resulting from works carried out on the French part, representing two thirds of the island's surface. Over 20 settlements are known for the Archaic, Early and Late Ceramic Ages, with a sequence of about 100 radiocarbon dates spanning from cal $3300 \mathrm{BC}$ to $1500 \mathrm{AD}$ (Bonnissent 2010; Bonnissent et al. 2013) (Figure 1B). Long-term and/or spatially extensive excavation of several of these sites permitted the recovery of abundant material remains as well as understanding of the structural and functional organisation of settlement space.

Large assemblages of invertebrate remains were recovered from these excavated materials, seven of which were analysed by the first author (Serrand 2002, 2004, 2005a, 2008, 2013a, b) and one of which was studied by A. Brokke (Anse des Pères; Brokke 1999). Due to high counts of abundance they are discussed in detail in this paper. The assemblages span almost completely the pre-Columbian sequence from the 4th millennium BC to the 12th century AD: three are Archaic Age sites, two are Early Ceramic Age villages and three date to the Late Ceramic Age (Figure 1). Invertebrate samples from the most recently 
occupied sites of Prune Bay (Bonnissent and Stouvenot 2005) and Red Bay (Hénocq and Petit 1998) extend up to the 15th century $\mathrm{AD}$ (Figure 1A, no. 11, 12), thus documenting the end of the pre-Columbian sequence, and will be analysed soon to complement our understanding of insular resource exploitation.

The details of the past invertebrate analyses have been reported elsewhere (Serrand 2002, 2004, 2005a, 2008, 2013a, b). These data are used here to address diet and subsistence; they are summarised and expressed in Theoretical Alimentary Values (\%TAV), an extrapolation which permits placing species into a hierarchy. TAV are obtained by multiplying each species' MNI by a theoretical coefficient proportionate to the mean size of the taxon in question, and thus indicate the relative contribution of that species to diet (Figure 2A).

Comparison of the data from the eight Saint-Martin sites (Etang Rouge 1-3, Lot 73, Orient Bay 1, Hope Estate, Anse des Pères, Pointe du Canonnier, Orient Bay 2, and BK76) and seven other settlements from nearby islands (Radio Antilles and Trants in Montserrat, Cathedrale and Gare Maritime de Basse-Terre in Guadeloupe, Dizac, Trabaud and Macabou in Martinique) reveals trends or even recurrent patterns. Although unsatisfactory, this comparison is made using the three major chrono-cultural partitions commonly followed in Caribbean archaeology: Archaic, Early Ceramic Age, and Late Ceramic Age

\section{Patterns of the Saint-Martin sequence and other neighbouring islands' sites}

\section{Archaic Age settlements}

Fourteen Archaic settlements between $3300 \mathrm{BC}$ and the early first century $\mathrm{AD}$ are known on Saint-Martin (Bonnissent 2010; Bonnissent et al. 2013, 2016) (Figure 1). Although two of these settlements are located farther from the coast, most known occupations are located on coastal sand bars in front of present-day or former lagoon areas (Bonnissent et al. 2016). The occupation sequences of these sand bars are the more marked as the same spots were visited over long periods of time, from one to two millennia at the three studied settlements (Figure 1B) (Romon, Bertran, and Serrand 2008; Bonnissent et al. 2016). Most of these occupations represent camp spots used repeatedly for the acquisition, preparation or use of animal, plant and stone resources (Bonnissent et al. 2016).

This is the case of the three most studied Archaic Age settlements, Etang Rouge (3320-830 BC), Lot 73 (1930-870 BC), and Orient Bay 1 (790 BC-70 AD) (Figure 1A, no. 1, 3, 4) (Serrand 2005a, 2008, 2013a; Romon, Bertran, and Serrand 2008; Bonnissent 2010, 2014; Bonnissent et al. 2005, 2013, 2016). The faunal assemblages at Etang Rouge and Lot 73 reflect food activities (preparation, consumption, or even stocking) of selected profitable marine bivalves with one dominant species at each camp zone: either ark clams (Arca zebra) or clams (Codakia orbicularis) (Figure 2B). In Orient Bay 1, a similar targeting was put on adult conchs (Lobatus gigas) to use their shell (especially the lips) for intensive production of adze tools (Figure 2B). This production and access to $L$. populations were key to the settlement of the Orient Bay 1 camps in this bay. Subsistence motives were less important than at Etang Rouge or Lot 73 as is witnessed by the fact that, in addition to conchs, only locally accessible molluscs and most easily accessible specimens were harvested (Serrand 2007a, 2013a).

These three sites share a heavy emphasis on and selection of specific resources, here mostly marine ones given the corpus of coastal sites. Targets and strategies vary among sites and across time (Bonnissent et al. 2016; Serrand 2008). For example, - at Etang Rouge 3, key resources found in temporarily successive camp areas differ, from an emphasis on ark clams, then ark clams and conchs, and finally clams (Serrand 2008). These trends are restricted in the range of targeted taxa, with only a few species consistently collected (ark clams, clams, oysters, conchs, topsnails). These selected species are probably related to combined, but as yet undetermined, economic, societal, seasonal and palaeo-environmental parameters. But, no matter the species' variations and the reasons, the exploitation strategies remain selective by nature. In fact, this is a very common trait for most Archaic settlements on Saint-Martin, as well as elsewhere in the northern Lesser Antilles (see synthesis in Serrand 2007a), whether the settlements are coastal or inland (as at the inland site of Plum Piece, for example) (Hofman and Hoogland 2003; Hofman, Bright, and Hoogland 2006). In addition, another recurrent trait is that shell use as a raw material (mostly conch ( $L$. gigas) and helmet (Cassis spp.) shells) is limited to tool production (adze and container types) with no known shell ornament manufacture for that period in the Lesser Antilles.

\section{Early Ceramic Age settlements}

The patterns diverge for the known Early Ceramic Age occupations associated with the Cedrosan-Saladoid subseries. Unfortunately, the Saint-Martin record is less abundant for this period, with four sites of which only two show typical characteristics of villages and possess large assemblages of invertebrates.

The most ancient Hope Estate settlement, two km from the coast, yielded a characteristic early Cedrosan-Saladoid ceramic assemblage with a Huecan component and dates ranging from $400 \mathrm{BC}$ to $700 \mathrm{AD}$ (Hofman and Hoogland 1999; Bonnissent, Hénocq, and Stouvenot 2002; Bonnissent 2010, 171-365) 
A

\begin{tabular}{|lll|}
\hline coefficient species & & $\begin{array}{l}\text { generalization to other species } \\
\text { other conchs, large gastropods }\end{array}$ \\
\hline 5 & Lobatus gigas & \\
\hline 4 & Cittarium pica & other large bivalves \\
4 & Arca zebra & other small gastropods \\
\hline 2 & Codakia orbicularis & other small bivalves \\
\hline 2 & nerites (Nerita peloronta, versicolor, tessellata) & crabs in general (except lobster) \\
\hline 2 & star shells (Lithopoma, Turbo spp.) & \\
\hline 2 & Donax denticulatus & other very small gastropods \\
\hline 1 & Gecarcinid land crabs & \\
\hline 1 & chitons & neritines (Neritina spp.) \\
\hline
\end{tabular}

Etang Rouge 1 \& 3

$\mathrm{MNI}=7819$

$\mathrm{MNI}=4866$
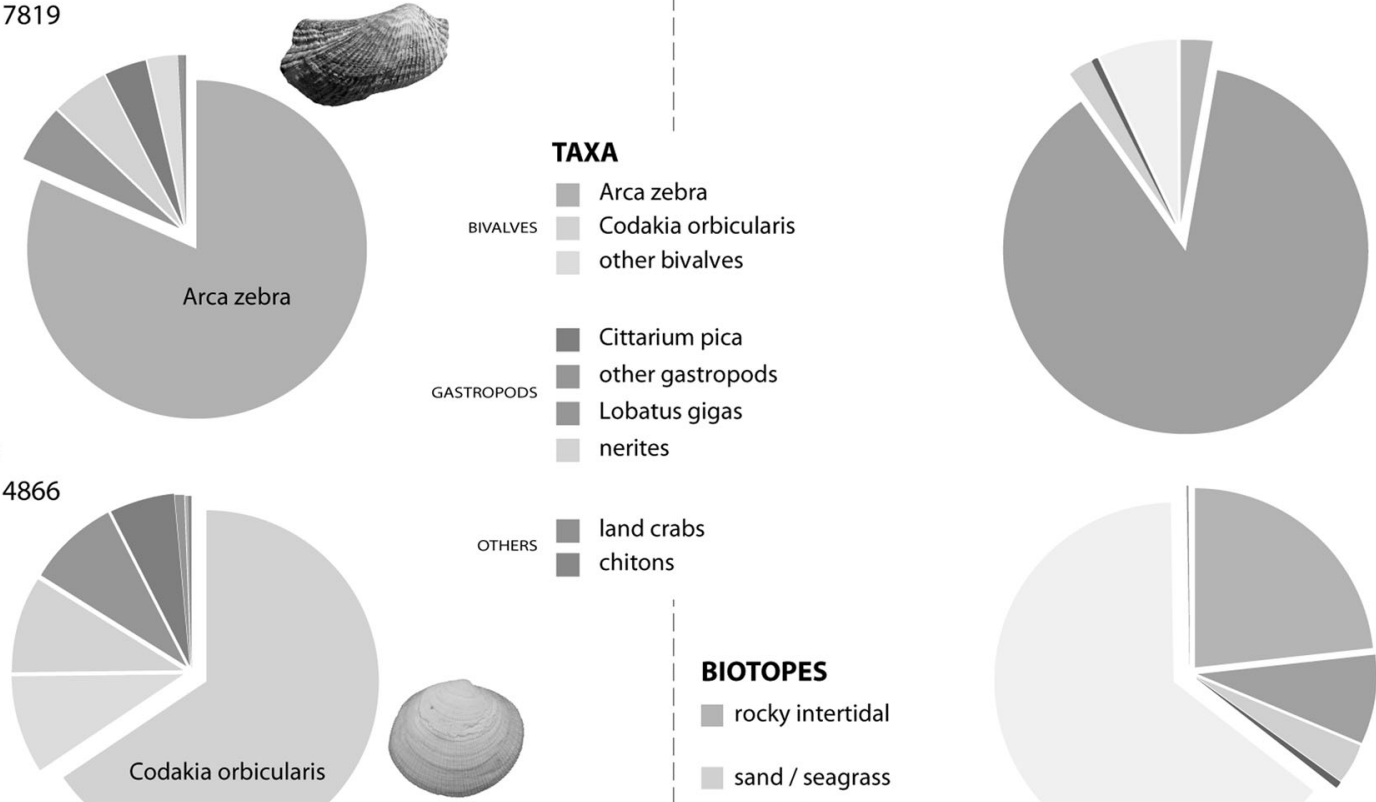

land crabs
chitons
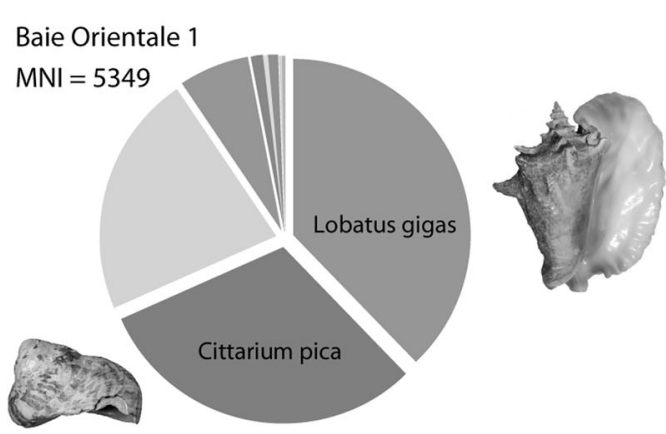

\section{BIOTOPES}

rocky intertidal

sand/ seagrass

sandy bottoms

coral sands

cobbles / reef

terrestrial / freshwater
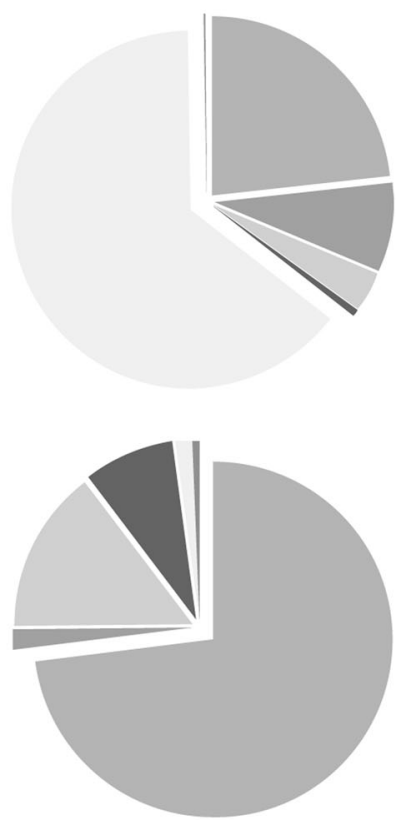

Figure 2. A. Synthetic table of theoretical coefficients used in the calculation of Theoretical Alimentary Values (\%TAV); B. Proportions of Theoretical Alimentary Values (\%TAV) per taxa in the three Saint-Martin Archaic Age sites of Etang Rouge 1-3, Lot 73 and Orient Bay 1; C. per biotope; Theoretical Alimentary Value (\%TAV) is an extrapolation used to put species into a hierarchy, obtained by multiplying each species MNI by a theoretical coefficient proportionate to the relative alimentary contribution of that species, supposing mean sized individuals.

(Figure 1A, no. 5). The latest one, Anse des Pères, while also characterised by Cedrosan-Saladoid ceramics, is dated to between 730 and $960 \mathrm{AD}$ which makes it contemporary with some Saint-Martin Late Ceramic Age sites (Hofman and Hoogland 1999; Bonnissent 2010,
391) (Figure 1A, no. 8). The two other, less documented sites, Pinel Ouest and Cul-de-Sac, appear as satellite camps and may be contemporaneous with the latest phase of Hope Estate (Bonnissent 2010, 367, 389) (Figure 1A no. 6, 7). 
The Hope Estate invertebrate assemblage shows that the villagers collected several different profitable marine species (Figure 3A) - topsnails Cittarium pica, conchs L. gigas and nerites (Nerita spp.) - which they complemented with terrestrial land crabs (Gecarcinids) and some easily accessible but less profitable species of the rocky intertidal areas (i.e. chitons, dog winkles, etc.) (Serrand 2002).

The paucity of data for the very Early Ceramic period on Saint-Martin, makes us turn to a few contemporary early sites of the neighbouring islands, for a larger view: on the island of Montserrat, Radio Antilles dated to ca. 500-40 BC and Trants, dated from ca. 500 BC to 400 AD (Watters 1980; Petersen 1996; Watters and Petersen 1999; Figure 1 no. 16, 17); and, on Guadeloupe, Cathedrale de Basse-Terre, dated to ca. 50-420 AD (Bonnissent et al. 2004a), and Gare Maritime de Basse-Terre, dated to ca. 240-540 AD (Romon et al. 2006, 2013) (Figure 1 no. 14, 15). These sites share characteristics of early Cedrosan-Saladoid villages, the two last being potentially parts of the same settlement. Their invertebrate samples are extensive, with the exception of Radio Antilles (only 410 MNI) (Serrand 2002, 2004, 2006).

These four settlements show similar trends in the exploitation of invertebrates, with an emphasis on resources collected, on the one hand, in terrestrial spaces (Figure 3B) - Gecarcinid land crabs and freshwater dwelling neritines (Neritina punctulata and N. virginea) and, on the other hand, on the interfaces between these terrestrial spaces and the marine environments, namely the intertidal rocky zones (nerites, chitons, limpets and various other small gastropods). This is associated with a constant, although sometimes discrete, contribution of conchs and topsnails. Notably, the profitable resources appreciated by the former Archaic groups i.e. large gregarious bivalves - are no longer exploited; indeed, bivalves are little represented if not totally absent (Serrand 2002, 2004, 2006, 2007a).

As in the former period, targeted prey vary between sites or during the occupations' sequences (Serrand 2002). Despite this variation, besides the constant inclusion of topsnails and conchs, exploitation strategies remain similarly focused on the accessible terrestrial and intertidal environments and their resources. Those are collected in quantities but with no targeting of the biggest species/specimens, in a pragmatic way. Another salient trait of the Early Ceramic Age assemblages is an intensive use of shells as raw material worked with a high level of technical skill (Serrand 2002, 2004, 2006, 2007a) that is characteristic of other Cedrosan-Saladoid craftproduction (Knippenberg 2006).

Both patterns remain relatively constant during the period but with a possible shift in resource exploitation for food in the end of the period. The later site of Anse des Pères (Figure 3C) is of particular interest since, while its ceramic assemblage is Cedrosan-Saladoid, its dates (730-960 AD; Hofman and Hoogland 1999; Bonnissent 2010,391) are later than typical for the accepted end of this cultural period. Now, the invertebrate data from this site (Brokke 1999, 105) shows differences with the very Early Ceramic Age Hope Estate site and its Montserrat and Guadeloupe contemporaries: while land crabs are still well represented (with a smaller mean size compared to the Hope Estate specimens; Serrand 2002), topsnails and the bivalve A. zebra predominate (Brokke 1995, 1999; Nokkert 1999). A. zebra contributes about $10 \%$ to invertebrate MNI at Anse des Pères. At Hope Estate or the montserratian sites, bivalves never account for more than $5 \%$ of the invertebrates' MNI and more often for less than $2 \%$. The pattern of increased contribution of bivalves to diet at Anse des Pères may be weakened by a small MNI (1001) but is worth underlying given that this trend becomes more marked in the following period of the Later Ceramic Age.

\section{Late Ceramic Age settlements}

The transition between the Early and Late phases of the Ceramic Age in Saint-Martin has been discussed in Bonnissent $(2010,536)$. Five Late Ceramic Age settlements are known from the island, all coastally located and dated to the 7th-16th centuries AD. The invertebrate assemblages from three of these sites - Pointe du Canonnier (unpublished), Orient Bay 2, and BK76 (77-78) have been well studied (Serrand 2013b, 2016). These three settlements are associated with ceramic assemblages of the Mamoran-Troumassoid subseries (Bonnissent 2010). Pointe du Canonnier (660 and $890 \mathrm{AD}$ ), the earliest, is a large village settlement (Bonnissent 2010, 397; 2012, 110-114). The Orient Bay 2 site (740-960 AD) is likely a camp for acquisition of stone and food resources (Bonnissent 2010, 150; Bonnissent et al. 2013). BK76 (77-78) (700 and 1170 $\mathrm{AD}$ ) is another large village occupation (Samuelian et al. 2016; Sellier-Segard and Samuelian, in press).

At these sites, invertebrate exploitation trends show some continuity from the former period, but with no such uniform patterns, as well as and heavy dominance of topsnails C. pica (Figure 4A). Other species from the rocky intertidal biotope, are remain important, especially nerites as well as conchs and star snails. Terrestrial / freshwater invertebrates - land crabs, neritines - when present generally occur in low numbers. Based on the abundance of infaunal bivalves, sandy bottom biotopes also tend to be better represented at these early Late Ceramic Age sites which is not surprising given their coastal locations (Figure 4B).

Now, this trend was underlined at the late Early Ceramic Age site of Anse des Pères (730-960 AD), which is contemporary with the Late Ceramic Age sites of Pointe du Canonnier and Orient Bay 2. At these three sites - the former possesssing Cedrosan-Saladoid 


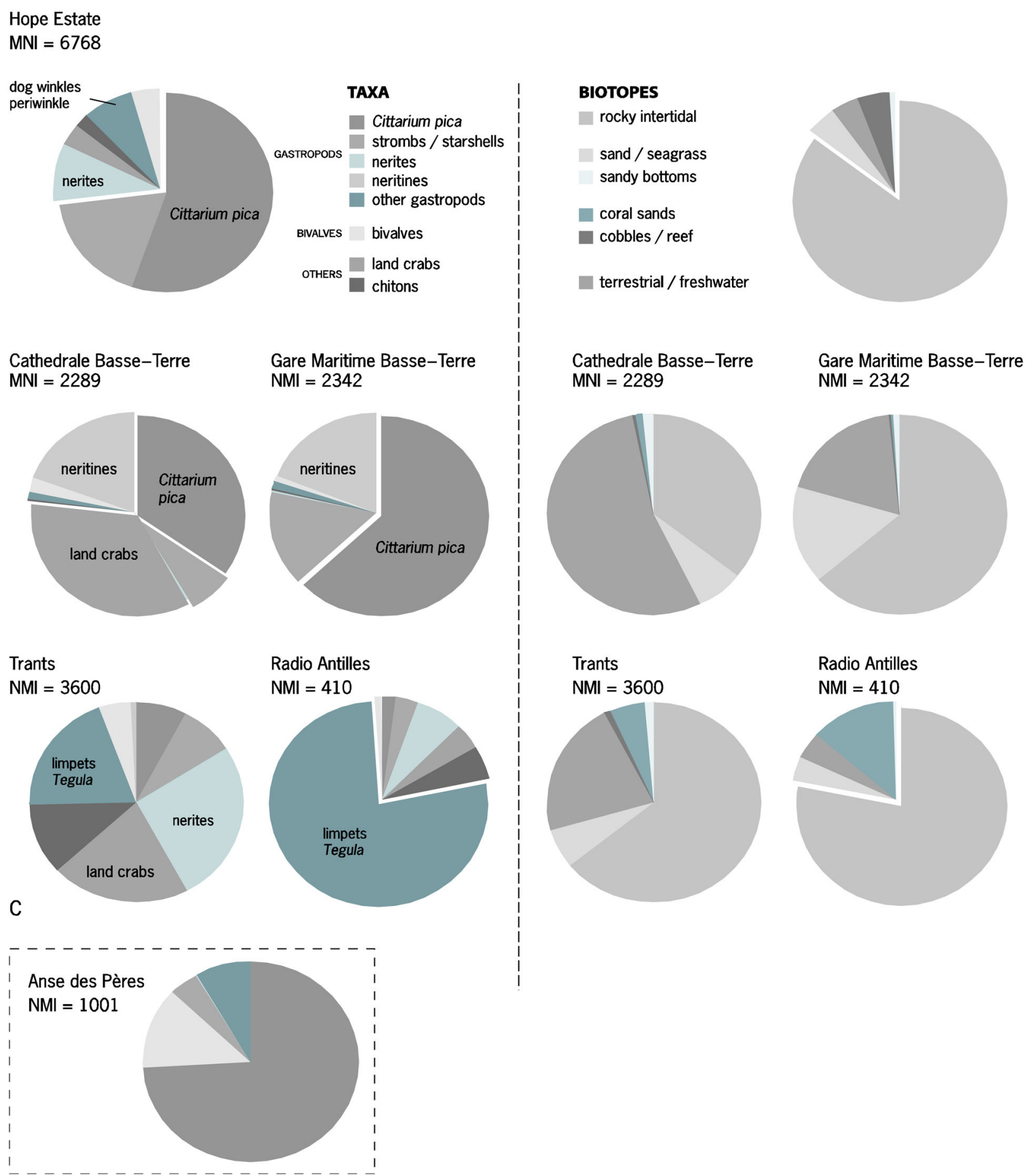

Figure 3. Proportions of Theoretical Alimentary Values (\%TAV) in the Early Ceramic Age sites of Hope Estate (Saint-Martin), Cathédrale and Gare Maritime de Basse-Terre (Guadeloupe), and Trants and Radio Antilles (Montserrat): A. per taxa; B. per biotope; C. The case of the Anse des Pères site.

ceramics and the latter two bearing Mamoran-Troumassoid ceramics - bivalves account for approximately $13 \%, 5 \%$ and $1.5 \%$ of the TAV, respectively. Notably, TAV values found at the early Early Ceramic Age sites previously described vary between $1 \%$ and $4.5 \%$. Increased bivalve representation is especially apparent at the Late Ceramic Age BK76 village, the latest analysed sequence, where bivalves, mostly from sandy bottoms, account for 20\% TAV (Serrand 2016). Additional analysis will need to be completed to determine whether this pattern also occurs at Prune Bay and Red Bay, where clams and ark clams are also well represented.

Additional insight is provided by comparing three sites from Martinique's southern coast: Dizac (450700 AD). a late Early Ceramic Age site with a late 


\section{Pointe du Canonnier}

$\mathrm{MNI}=3176$

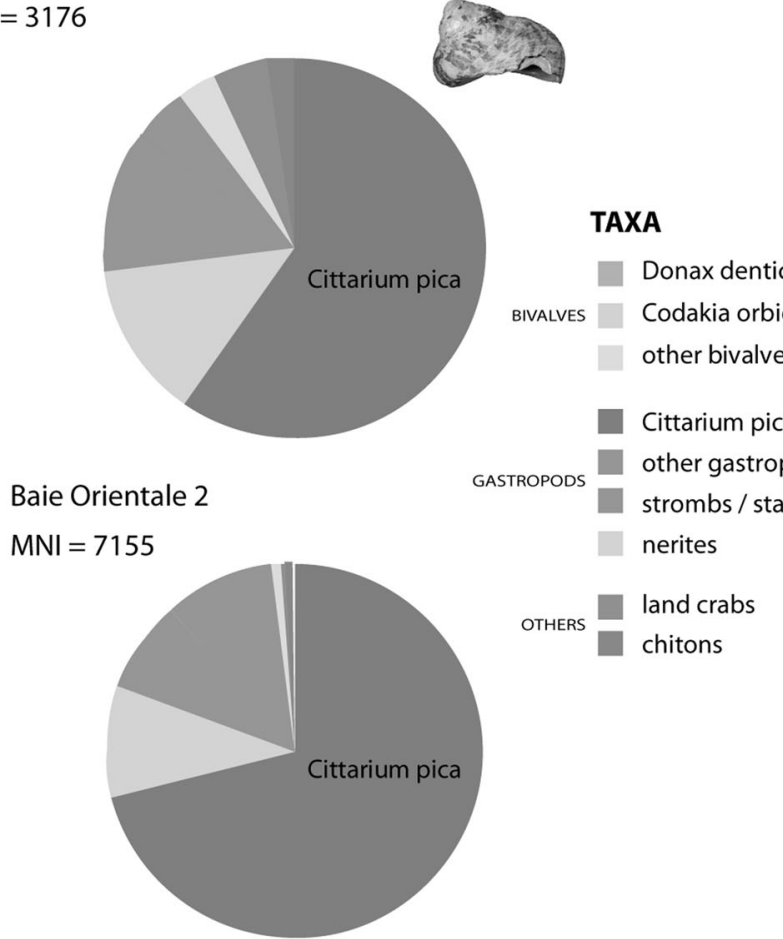

\section{BIOTOPES}

rocky intertidal

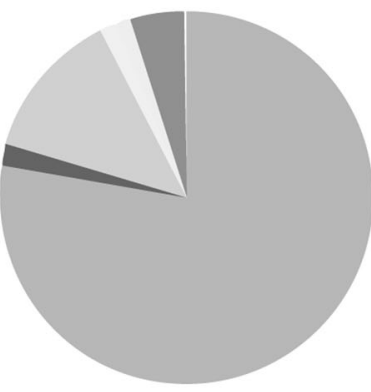

BK76

sand / seagrass

sandy bottoms

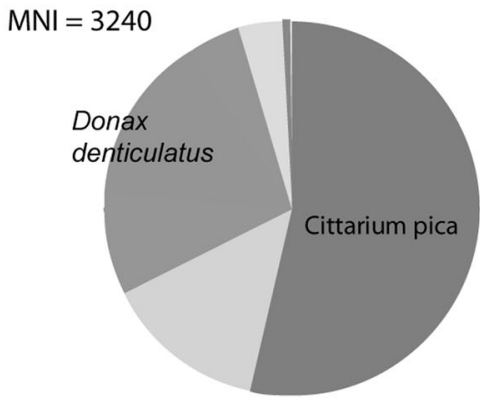

coral sands

cobbles / reef

terrestrial / freshwate

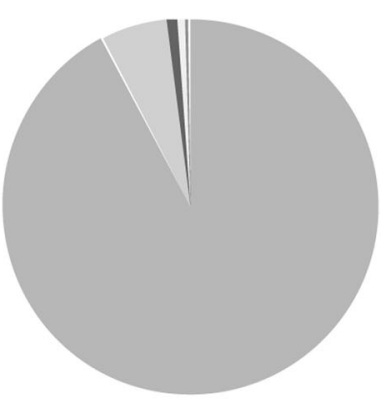

Figure 4. Proportions of Theoretical Alimentary Values (\%TAV) in the three Saint-Martin Late Ceramic Age sites of Pointe du Canonnier, Orient Bay 2 and BK 76: A. per taxa; B. per biotope.

Cedrosan-Saladoid assemblage (Vidal 1999; Serrand 2005b) (Figure 1 no. 18); and Trabaud (1000-1200 AD) and Macabou (1200-1400) AD, both Late Ceramic Age sites (Allaire 1981, 1997; Grouard and Serrand 2005) (Figure 1 no. 19, 20). Exploitation profiles at these sites indicate diverse species exploitation, dominated by bivalves (45-90\% TAV), particularly bivalves from sandy bottoms (Figure 5) (Serrand 2007b).

\section{Discussion}

\section{Insights into the pre-Columbian Lesser Antilles} socio-economic systems through the perspective of invertebrate exploitation

Following the simplified three chrono-cultural partitions commonly used in Caribbean archaeology, several notable trends are evident in the invertebrate data examined here.

\section{Lesser Antillean}

The targeting of invertebrate resources is a major strategy of Lesser Antilles Archaic communities (Serrand 2007a), as evidenced by the remains from the SaintMartin non-sedentary camps, which were temporarily but repeatedly occupied for specialised activities organised around specific resources. This pattern appears prevalent on other islands, varying according to the resources and environments locally targeted, as on in Saint-Martin, for example, where sand bar-lagoon systems were selected for exploitation. The way the Archaic populations managed their economic spaces and components implied some mobility of the groups and their good knowledge of territories and resources. 
A. per taxa

Diamant (Dizac)

$\mathrm{MNI}=3286$

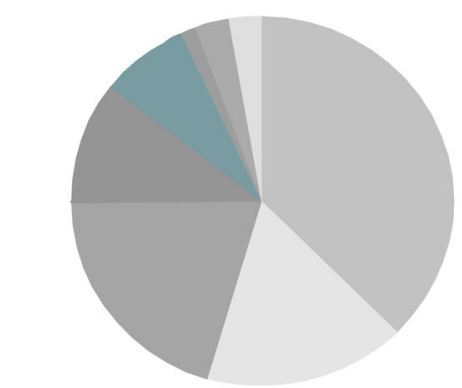

Trabaud

$\mathrm{MNI}=552$

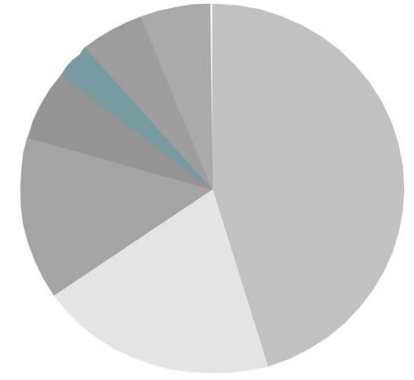

Macabou

$\mathrm{MNI}=4806$

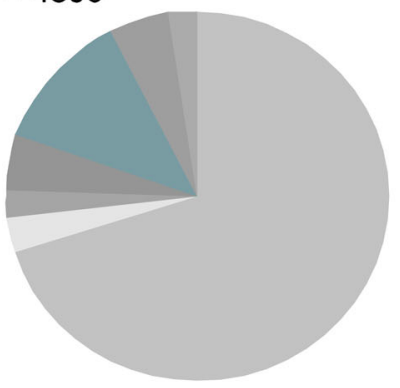

\section{B. Per biotope}

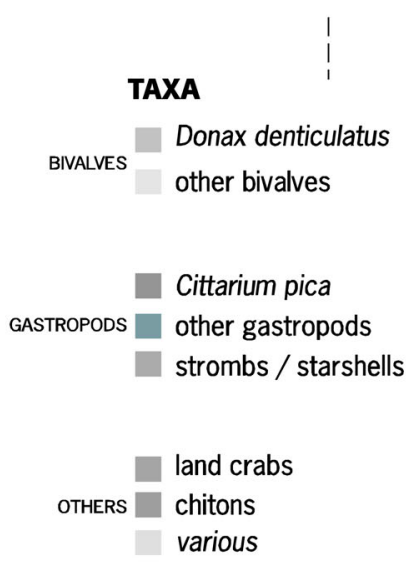

\section{BIOTOPES}

rocky intertidal

sand / seagrass

sandy bottoms

coral sands

cobbles / reef

terrestrial / freshwater

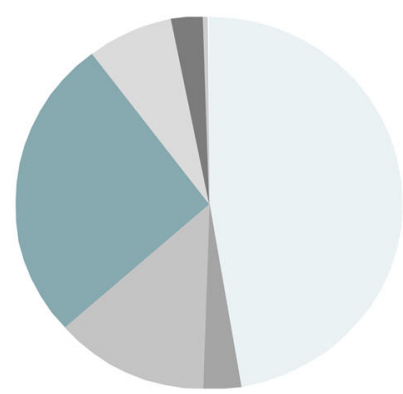

Figure 5. Proportions of Theoretical Alimentary Values (\%TAV) in three Martinique sites: Diamant (Dizac), late Early Ceramic Age site, Trabaud and Macabou, Late Ceramic Age sites: A. per taxa; B. per biotope.

This sort of flexibility based on an array of possible options may have helped Archaic peoples optimally manage various territories and complementary economic resources (Hofman, Bright, and Hoogland 2006), but may have also meant that they were vulnerable to fluctuations in these resources and environments over time.

Lesser Antillean Early Ceramic communities appear to have gathered select but mostly easily accessible invertebrate resources from a limited range of terrestrial, freshwater, and marine settings, with no evident preference for high-energetic return species with the possible exception of land crabs (Serrand 2007a). The territorial and economic strategy of these communities appear to have involved returning selected resources to the residential area: the villages were central units around which the community economy was organised, supplemented by extra territorial resources obtained through trade and contacts (i.e. stone resources, finished goods, shell ornaments). Mobility, while active in communities' inter-relations and exchanges, may be less a foundation of the everyday economy whichseems consistent with the sedentary nature of Ceramic Age village communities and with their important agricultural orientations. We interpret the consistency, even relative conservatism, in resource exploitation during this period, along with rather standardised craft styles and productions, as a sign of strong social and identity cohesion inherent in the colonisation and settlement formation processes in which these groups were involved. Subsequent developments in later sites arise from economic and societal changes as well evolving biotope and resource changes due to anthropogenic impacts and changing palaeo-climatic and environmental contexts (Haviser 1991). 
The economic systems of Lesser Antilles Late Ceramic Age communities present interpretive complexities. These groups are classically considered as being part of a much larger mosaic of populations (spread across the whole archipelago), settling in a higher variety of locations, and exhibiting more complex system of spatial organisation (satellite-, micro-, specialised occupations, etc.). The new diverse craft styles and productions are interpreted as signs of a regionalisation process, as well as in some places, of a growing socio-political complexity. In this period, exploitation strategies may have depended more on sites' functional organisation with respect to this more socially interactive and multi-scalar economic spatial sphere. Late Ceramic Age peoples may also have been reliant on a more impacted resource base (Serrand 2007a). In the absence of a broader understanding of the site functions and outside interactions, it is difficult to reach any firm conclusions about resource exploitation patterns exhibited at these sites.

\section{The issue of palaeo-climatic and palaeo- environmental parameters}

While patterns of invertebrate exploitation provide an insight into the socio-economic systems of the Lesser Antilles pre-Columbian communities, these developed on 'living islands' with changing biographies (Cooper and Boothroyd 2011). Examining the socio-economic data presented here within the context of changing palaeo-climate may thus offer additional understanding. On Saint-Martin, multiproxy analysis of lacustrine sediments from the Grand-Case Pond in the northwestern part of the island has revealed the existence of three distinct climatic periods for the last 3700 years (Bertran et al. 2004; Bonnissent et al. 2004b; Malaizé et al. 2011). Several indicators (carbonate mud deposition, gypsum laminae, hurricane landfalls, sand inputs) suggest that two separate phases, between 3700 and ca. 2500 years cal. BP (1750-550 cal BC) and between 1150 years cal. BP to the present $(800-1550 \mathrm{cal}$ $\mathrm{AD}$ ), were punctuated by severe drought events as well as higher hurricane occurences. The intermediate time interval, from 2500 to $1150 \mathrm{yr}$ cal. BP (550 cal BC-800 cal AD), would have been marked by more uniform and wetter climatic conditions (Malaizé et al. 2011) (Figure 6). The existence of such wet / dry phases and hurricane activity variations, relate to movements of the Intertropical Convergence Zone (ITCZ). Such a climatic history agrees closely with that documented from other records in the Caribbean area, such as the Cariaco Basin, central coast of Belize or Barbados (Carbone 1980; Higuera-Gundy 1991; Hodell et al. 1991; Burney, Burney, and MacPhee 1994; Tedesco and Thunell 2003; Mangini et al. 2007). Nevertheless, it contrasts with the pattern observed in Vieques, Puerto Rico (Woodruff et al. 2008), where phases of hurricane activity differ probably due to a balance between two distinct storm paths in response to latitudinal shifts
A

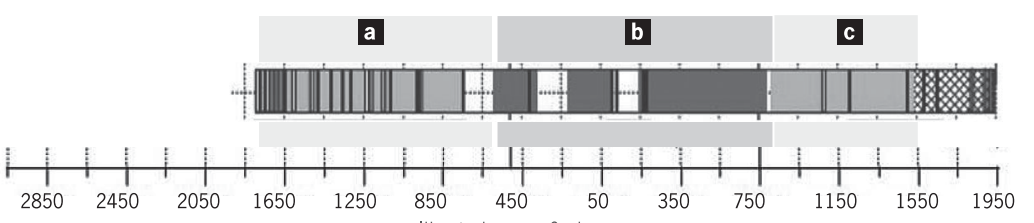

B

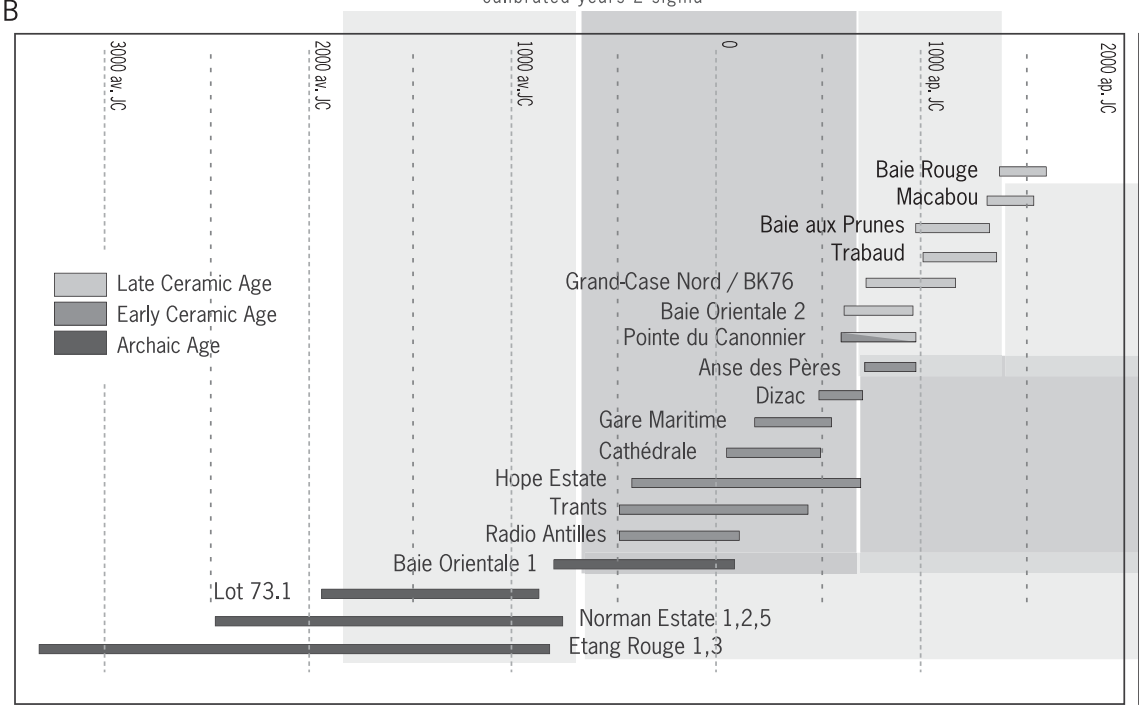

a, b, c after Malaizé et al. 2011

(a) dry period from 3700 to $\sim 2500 \mathrm{yr}$ cal. BP ( 1750 - 550 cal bc)

(b) wet phase from 2500 to $1150 \mathrm{yr}$ cal. BP

( $550 \mathrm{cal}$ bc $-800 \mathrm{cal} \mathrm{ad})$

(c) dry phase from 1150 to $400 \mathrm{yr}$ cal. BP

( $800-1550 \mathrm{cal}$ ad)

C

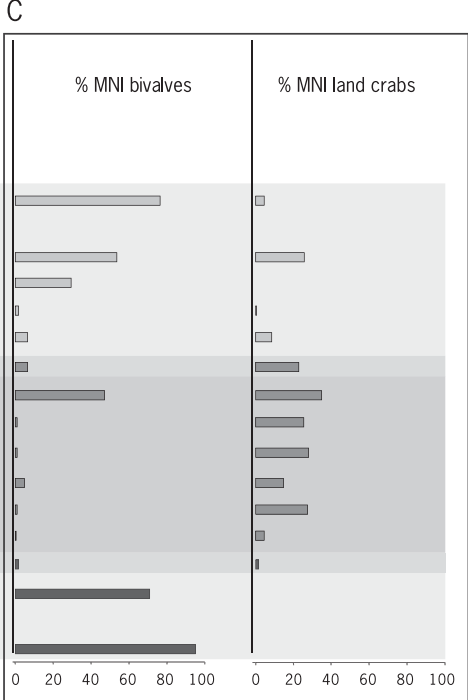

Radiometric dates in calibrated calendar years of the 27 pre-Columbian settlements of Saint-Martin (2 sigma, 95\% probability) (Bonnissent 2015)

The correction of the marine reservoir effect was applied when needed

Figure 6. A. Palaeoclimatic dry / wet phases on Saint-Martin; B. Indication of the dry / wet phases on the chart of radiometric dates of the sites udes in the study; C. Variations of the proportions of MNI for bivalves and land crabs on the sites used in this study. A and B after Malaizé et al. 2011, fig. 11, p.11; B after Bonnissent et al. (2016). 
of the Intertropical Convergence Zone (ITCZ). (Malaizé et al. 2011).

We chose to compare these three Saint-Martin climatic phases, with local site chronology (Figure 6, a, b, c) and the temporal trends for two components of the invertebrates' assemblages presented above: terrestrial-freshwater molluscs and crabs; and bivalves on the other. The relevant data are presented in Figure 6 as MNI for the 15 sites listed above. Figure 7 includes 13 other assemblages with smaller MNI that were also

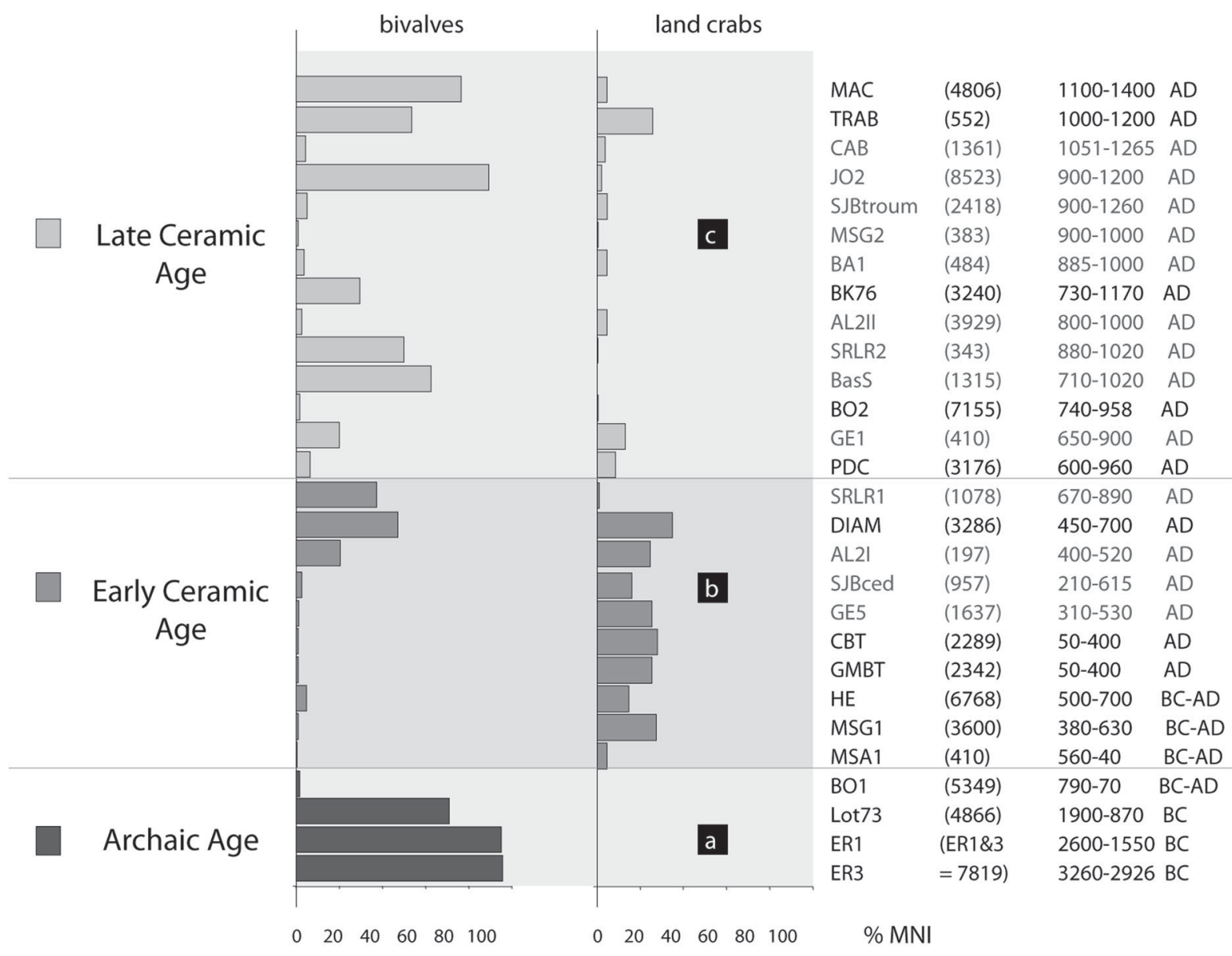

a, b, c after Malaizé et al. 2011
(a) dry period from 3700 to $\sim 2500 \mathrm{yr}$ cal. BP $(\sim 1750-550 \mathrm{cal} \mathrm{bc})$
(b) wet phase from 2500 to $1150 \mathrm{yr}$ cal. BP $(\sim 550 \mathrm{cal} \mathrm{bc}-800 \mathrm{cal} \mathrm{ad})$
(c) dry phase from 1150 to $400 \mathrm{yr}$ cal. BP $(\sim 800-1550 \mathrm{cal} \mathrm{ad})$

bold: Saint-Martin sites mentioned in details in this study

oblique: Guadeloupe, Montserrat and Martinique sites mentioned in details in this study

regular light: additional sites (and phases) from various islands studied by the first author:

GE5: Hichman's, Nevis (Wilson 1989; Serrand 2002)

SJB: Stade J. Bade, Marie-Galante, SJBced: cedrosan Saladoid phase ; SJBtroum: Troumassoid phase (Serrand et al. 2016)

AL2: Rendezvous Bay, Anguilla, AL2I: early phase, AL2Il: late phase (Watters andPetersen 1993; Serrand 2002)

SRLR: Sainte-Rose La Ramée, Guadeloupe, SRLR1: early phase, SRLR2: late phase (Casagrande et al. 2014)

GE1: Indian Castle, Nevis (Wilson 1989; Serrand 2002)

BA1: Indiantown Trail, Barbuda (Watters 1980; Watters et al. 1992; Serrand 2002).

MSG2: Windward Bluff, Montserrat (Watters 1980; Serrand 2002)

JO2: Sulphur Ghaut, Nevis (Wilson 1989; Serrand 2002)

CAB: Caille à Bélasse, Petite-Terre, Guadeloupe (Gagnepain 2007)

BasS: Bas-de-la-Source, Marie-Galante, Guadeloupe (Stouvenot 2004)

Figure 7. A. Confrontation of the palaeoclimatic dry / wet phases recognised on Saint-Martin (after Malaizé et al. 2011, figure 11, p. 11) and the relative proportions of MNI for bivalves and land crabs from 28 Lesser Antillean sites studied by the first author. The sites are organised along a theoretical temporal sequence: the radiometric date ranges overlap between sites and the projection doesn't represent a formal continuity of time. 
studied by the first author (list, radiocarbon intervals, and bibliographical references in Figure 7). Both figures show that terrestrial-freshwater molluscs and crabs are rare in Archaic sites assemblages, well represented in the subsequent Early Ceramic Age sites, then generally (but not systematically) declined in the Late Ceramic Age sites. In that same sequence, bivalves fluctuate inversely (Serrand 2007a).

The alignment of these palaeo-climatic and archaeofaunal data is admittedly course, and much more finegrained work will need to be carried out utilising radiometric dates, site contexts and functions alongside palaeo-climatic data. Nevertheless, some trends emerge which suggest that the changing relative contributions of terrestrial-freshwater molluscs and crabs to bivalves may have some paleo-climatic basis: indeed, the increased representation of lands crabs seems to partly coincide with the wet phase, while higher frequencies of bivalves are seen mostly during dry phases. This is particularly interesting since these two types of resources are key targeted prey and possible cultural markers of specific periods, namely the Archaic Age for the bivalves and the Early Ceramic Age for the terrestrial crabs.

These trends show that we need to address how much the variability and instability of climate and environments were potential factors at play in the decision-making processes of pre-Columbian societies, along with cultural, demographic, political, and economic parameters (Bonnissent et al. 2004b; Cooper and Peros 2010). It is obvious that gradual (e.g. sea-level changes, increased aridity) or abrupt (e.g. hurricanes, heavy swells) climatic changes have had consequences on the coastal biotopes where most invertebrate resources were collected. These consequences were probably more significant for resources which had been previously stressed or weakened by long-term exploitation (or even over-predation). This latter situation could apply to the land crabs which exploitation was intensive during the Early Ceramic Age and, globally, less important afterwards. Signs of a decrease of the individuals' mean size have been observed, in time, on sites or between early and later sites (Serrand 2002) but this issue has never been clearly established.The short or long-term impacts on the availability of such resources through time and the duration of resilience mechanisms, although not yet understood, clearly generated nonlinear or non-conclusive dynamics with reciprocal feedback loops, time lags, legacy effects, etc. (Liu et al. 2007).

\section{Conclusion}

The island of Saint-Martin was struck in September 2017 by Irma, one of the most significant hurricanes of the last several decades. It caused massive destructions of human facilities and deep alterations of natural, already stressed and weakened, environments, notably coastal ones.

Similar dramatic events as well as more gradual fluctuations in climate, such as alternating dry-wet seasons or sea level changes, have impacted the water availability and landscapes of Caribbean islands in the past. The consequences of the abrupt events (hurricanes, heavy swells) may have been rather local (on the scale of one or a few islands) and less easy to detect in the archaeological record (Cooper and Sheets 2012), while their longer-term effects, combined with the gradual fluctuations may be read on larger, regional scales. All these likely had implications at various scales for the economic and social landscapes of pre-Columbian communities, especially with respect to their settlement and food procurement strategies, as well as, possibly, their regional networks organisation, cosmogony, etc.

Analyzing the exploitation of resources and food procurement strategies, and their changes over time thus remains one preferential area of research for understanding human-environmental relations in the past (Cooper and Peros 2010). It provides elements for exploring possible interactions between environmental circumstances (potentials, constraints), including climate-induced environmental pressures and human-induced stresses on fauna or biotopes, and cultural decisions (particular cultural lifeways) in relation to all other components of the communities' systems (including spiritual).

Employing a deep-time perspective, we have sought to outline these elements here for the island of Saint-Martin using an archaeo-faunal record contextualised within the framework of available climate data. Although preliminary, this sketch based on a long-term synthesis provides new insights into understanding pre-Columbian social-ecological systems.

Nevertheless, if the dynamic nature of environments, especially on islands, implies necessary readjustments of the human groups and mitigation strategies, the responses are complex, not necessarily rational or optimal and include nonlinear dynamics, reciprocal feedback loops, time lags, legacy effects (Liu et al. 2007) the impact of which may be unclear in the archaeological record.

Understanding these intricate dynamics therefore needs improvement and actual integration and extended synthesis of archaeological, bio-archaeological, and palaeo-environmental sources of information and the s. As in other regions, this is a major research priority in the archaeology of the island Caribbean with relevance to modern day mitigation strategies to counter the impacts of climate change in the Caribbean and elsewhere (see Dearing et al. 2015). 


\section{Disclosure statement}

No potential conflict of interest was reported by the authors.

\section{Notes on contributors}

Nathalie Serrand in charge of research at the Institut National de Recherches Archéologiques Préventives, DOM-TOM. Archaeologist and archaeomalacologist, specialized in the Antillean pre-Columbian societies economies.

Dominique Bonnissent Conservatrice régionale de l'archéologie de Guadeloupe, Ministry of Culture and Communication. Archaeologist and ceramologist, Antillean preColumbian archaeology.

\section{ORCID}

Nathalie Serrand (D) http://orcid.org/0000-0001-6283-5183

\section{References}

Allaire, Louis. 1981. "Macabou Excavations, Martinique: 1972-1979.” Boletin del Museo del Hombre Dominicano 10 (16): 41-48.

Allaire, Louis. 1997. “Anse Trabaud: Rapport 1997.” In Le Néolithique de la Martinique dans son Contexte Antillais, edited by Jean-Pierre Giraud, 0-6. Fort-deFrance: Service régional d'Archéologie. Projet collectif de recherche, Service Régional d'Archéologie Martinique, Martinique, Fort-de-France.

Bertran, Pascal, Dominique Bonnissent, Didier Galop, Daniel Imbert, Pierre Lozouet, Nathalie Serrand, and Christian Stouvenot. 2004. "Paléoclimat des Petites Antilles depuis 4000 ans BP: l'Enregistrement de la Lagune de Grand-Case à Saint-Martin.” Comptes Rendus Geoscience 336: 1501-1510.

Bonnissent, Dominique. 2010. Archéologie précolombienne de l'Ile de Saint-Martin, Petites Antilles. Des Campements des Nomades des Mers aux Villages des Agriculteurs-potiers (3300 BC-1600 AD). Sarrebruck: Editions Universitaires Européennes. 627 p.

Bonnissent, Dominique. 2012. "Saint-Martin, Pointe du Canonnier." Bilan Scientifique Régional 2012, Direction régionale des Affaires Culturelles Guadeloupe, Service Régional de l'Archéologie, Basse-Terre, 110-114.

Bonnissent, Dominique. 2014. "Saint-Martin, Les TerresBasses, Lot 73.” Bilan Scientifique Régional 2014, Direction régionale des Affaires Culturelles Guadeloupe, Service Régional de l'Archéologie, Basse-Terre, 162-165.

Bonnissent, Dominique, Pascal Bertran, Antoine Chancerel, Pierrick Fouéré, Sandrine Grouard, Franck Mazéas, Auran Randrianasolo, Thomas Romon, Nathalie Serrand, and Christian Stouvenot. 2013. Les Gisements Précolombiens de la Baie Orientale: Campements du Mésoindien et du Néoindien sur l'Ile de Saint-Martin (Petites Antilles). Directed by Dominique Bonnissent, Paris: Éditions de la Maison des Sciences de l'Homme, 245 p. (Documents d'archéologie française 107).

Bonnissent, Dominique, Pascal Bertran, Pierrick Fouéré, and Nathalie Serrand. 2005. Cultures précolombiennes des Petites Antilles. Les Occupations Précéramiques de l'Étang Rouge 1. Baie Rouge, les Terres Basses, Île de Saint-Martin, Région Guadeloupe. Rapport d'opération de Fouille archéologique préventive, Inrap Grand-Sud-
Ouest, Service Régional d'Archéologie de Guadeloupe, Basse-Terre, $190 \mathrm{p}$.

Bonnissent, Dominique, Pascal Bertran, Didier Galop, Daniel Imbert, and Christian Stouvenot. 2004b. "Chronologie des Occupations Précolombiennes de l'Ile de Saint-Martin (Petites Antilles) et Relations avec les Paléo-environnements." In 129e Congrès National des Sociétés Historiques et Scientifiques: Méthodologie du Temps Géologique, Besançon, 2004, Paris: Éditions du CTHS, 306-307.

Bonnissent, Dominique, Christophe Hénocq, and Christian Stouvenot. 2002. "Le Site Amérindien de Hope Estate (Saint-Martin, Petites Antilles): Extension et Chronologie." In Archéologie Précolombienne et Coloniale des Caraïbes, Actes du 123e Congrès National des Sociétés Historiques et Scientifiques, Antilles/ Guyane 1998, edited by André Delpuech, Jean-Pierre Giraud, and Albert Hesse, 177-194. Paris: Éditions du CTHS.

Bonnissent, Dominique, Thomas Romon, Pascal Bertran, and Nathalie Serrand. 2004a. Le Site de la Cathédrale de Basse-Terre, Guadeloupe. Rapport d'opération de Fouille archéologique préventive, Inrap Grand-Sud-Ouest, Service Régional d'Archéologie de Guadeloupe, BasseTerre, $269 \mathrm{p}$.

Bonnissent, Dominique, Nathalie Serrand, Laurent Bruxelles, Pierrick Fouéré, Sandrine Grouard, Nathalie Sellier-Segard, and Christian Stouvenot. 2016. "Archéoécologie des Sociétés Insulaires des Petites Antilles au Mésoindien: l'Enjeu des Ressources à SaintMartin.” In Archéologie des Chasseurs-cueilleurs Maritimes: de la Fonction des Habitats à l'Organisation de l'Espace littoral. Actes de la séance de la Société Préhistorique Française, Rennes, 10-11 avril 2014, edited by Catherine Dupont, and Grégor Marchand, 213260. Paris: Séances de la Société préhistorique française 6.

Bonnissent, Dominique, and Christian Stouvenot. 2005. "Un site d'Habitat postsaladoïde dans les Terres Basses (Plum Bay): Baie aux Prunes (Saint-Martin, Petites Antilles). "In Proceedings of the XXth International Congress for Caribbean Archaeology, Santo Domingo, 6-13 July 2003, edited by Glenis Tavárez, and María y Manuel A. García Arévalo, Museo del Hombre Dominicano y Fundación García Arévalo, 31-39.

Boomert, Aarie. 2000. Trinidad, Tobago and the Lower Orinoco Interaction Sphere. An Archaeological Ethnohistorical Study. Alkmaar: Cairi Publications, 578 p.

Brokke, Alex J. 1995. "Shell, Past to Present. Shellfish Gathering at Norman Estate and Anse des Pères". Master's thesis, Leiden University of Prehistory.

Brokke, Alex J. 1999. "Part Two: Anse des Pères. 9. Shell.” In Archaeological Investigations on St. Martin (Lesser Antilles). The Sites of Norman Estate, Anse des Pères and Hope Estate with a Contribution to the "La Hueca Problem", edited by Corinne L. Hofman, and Menno L. P. Hoogland, 105-110. Leiden: Faculty of Archaeology, Archaeological Studies Leiden University.

Burney, David A., Lida Pigott Burney, and Ross D. E MacPhee. 1994. "Holocene Charcoal Stratigraphy from Laguna Tortuguero, Puerto Rico and the Timing of Human Arrival on the Island." Journal of Archaeological Science 21: 273-281.

Carbone, Victor A. 1980. "The Palaeoecology of the Caribbean Area." The Florida Anthropologist 33 (3): 99119.

Cooper, Jago, and Richard Boothroyd. 2011. "Living Islands of the Caribbean. A View of Relative Sea Level Change 
from the Water's Edge." In Communities in Contact. Essays in Archaeology, Ethnohistory and Ethnography of the Amerindian Circum-Caribbean, edited by Corine L. Hofman, and A. Van Duijvenbode, 393-405. Leiden: Sidestone Press.

Cooper, Jago, and Matthew Peros. 2010. "The Archaeology of Climate Change in the Caribbean." Journal of Archaeological Science 37: 1226-1232.

Cooper, Jago, and Payson Sheets, eds. 2012. Surviving Sudden Environmental Change. Answers from Archaeology. Colorado: University Press of Colorado, $288 \mathrm{p}$.

Dearing, J. A., B. Acma, S. Bub, F. M. Chambers, X. Chen, J. Cooper, D. Crook, et al. 2015. "Social-Ecological Systems in the Anthropocene: The Need for Integrating Social and Biophysical Records at Regional Scales." The Anthropocene Review 2 (3): 1-27.

Fitzpatrick, Scott M. 2015. "The Pre-Columbian Caribbean: Colonization, Population Dispersal, and Island Adaptations." PaleoAmerica 1 (4): 305-331.

Grouard, Sandrine, and Nathalie Serrand. 2005. Rapport de Fouille Programmée du Site Amérindien de Macabou. Rapport d'opération de Fouille archéologique programmée, Service Régional d'Archéologie de Martinique, Fort-de-France, 129 p.

Haviser, Jay B. 1988. An Archaeological Survey of St. Martin St. Maarten. Reports of the Institute of Archaeology and Anthropology of the Netherland Antilles 7, 55 p.

Haviser, Jay B. 1991. "Development of a Prehistoric Interaction Sphere in the Northern Lesser Antilles." New West Indian Guide / Nieuwe West-Indische Gids 65 (34): 129-151.

Haviser, Jay B. 1995. In Search of St. Martin's Ancient Peoples, Prehistoric Archaeology. St. Martin: July Tree Books, House of Nehesi Publishers, 48 p.

Hénocq, Christophe, and François Petit. 1998. "Baie Rouge, Gisement Archéologique Tardif de Saint-Martin." In Proceedings of the XVIth International Congress for Caribbean Archaeology, Basse-Terre 1995. Conseil Régional de la Guadeloupe, Mission Archéologique et du Patrimoine, tome I, Guadeloupe, 316-332.

Higuera-Gundy, Antonia. 1991. "Antillean Vegetational History and Palaeoclimate Reconstructed from the Palaeolimnological Record of Lake Miragoane, Haiti." Ph.D. dissertation, Gainesville: University of Florida.

Hodell, David A., Jason H. Curtis, Glenn A. Jones, Antonia Higuera-Gundy, Mark Brenner, Michael W. Binford, and Kathleen T. Dorsey. 1991. "Reconstruction of Caribbean Climate Change Over the Past 10,500 Years." Nature 352: 790-793.

Hofman, Corinne L., Alistair J. Bright, and Menno L. P. Hoogland. 2006. "Archipelagic Resource Procurement and Mobility in the Northern Lesser Antilles: The View from a 3000-Year-Old Tropical Forest Campsite on Saba." Journal of Island and Coastal Archaeology 1: $1-20$.

Hofman, Corinne L., and Menno L.P. Hoogland, eds. 1999. Archaeological Investigations on St. Martin (Lesser Antilles). The Sites of Norman Estate, Anse des Pères and Hope Estate with a Contribution to the 'La Hueca Problem'. Leiden University the Netherlands: Archaeological Studies Leiden University, Faculty of Archaeology, $329 \mathrm{p}$.

Hofman, Corinne L., and Menno L.P. Hoogland. 2003. "Plum Piece. Evidence for Archaic Seasonal Occupation on Saba, Northern Lesser Antilles Around 3300 BP." Journal of Caribbean Archaeology 4: 12-27.
Keegan, William F. 1999. "Recent Climatic and Sea Level Fluctuations in Relation to West Indian Prehistory." In Proceedings of the 16th International Congress of the Association for Caribbean archaeology, Guadeloupe 1995, Conseil régional de la Guadeloupe, Mission archéologique et du Patrimoine, Basse-Terre, Guadeloupe, 95-104.

Knippenberg, Sebastiaan. 2006. "Stone Artefact Production and Exchange among the Northern Lesser Antilles." PhD diss., Leiden University, Faculty of Archaeology, department of Caribbean Archaeology, Utrecht, 382 p.

Lenoble, Arnaud, Sandrine Grouard, Fabrice Casagrande, Nathalie Serrand, and Thomas Romon. 2008. Faune Fossile des Cavités de Guadeloupe. Rapport de prospection thématique et de sondages, Service régional de l'Archéologie, DAC Basse-Terre, $40 \mathrm{p}$.

Liu, Jianguo, Thomas Dietz, Stephen R. Carpenter, Marina Alberti, Carl Folke, Emilio Moran, Alice N. Pell, et al. 2007. "Complexity of Coupled Human and Natural Systems." Science 317: 1513-1516.

Malaizé, Bruno, Pascal Bertran, Pierre Carbonel, Dominique Bonnissent, K. Charlier, Didier Galop, Daniel Imbert, Nathalie Serrand, Christian Stouvenot, and C. Pujol. 2011. "Hurricanes and Climate in the Caribbean During the past 3,700 yrs B.P.” The Holocene 21: 911-924.

Mangini, A., P. Blumbach, P. Verdes, C. Spötl, D. Scholz, S. Machel, and S. Mahon. 2007. "Combined Records from a Stalagmite from Barbados and from Lake Sediments in Haiti Reveal Variable Seasonality in the Caribbean between 6.7 and 3 ka B.P." Quaternary Science Reviews 26: $1332-1343$.

Newsom, L. A., and Elizabeth S. Wing. 2004. On Land and Sea. Native American Uses of Biological Resources in the West Indies. Tuscaloosa, London: The University of Alabama Press, 323 p.

Nokkert, Mark. 1999. "Part Two: Anse des Pères. Faunal Exploitation." In Archaeological Investigations on St. Martin (Lesser Antilles). The Sites of Norman Estate, Anse des Pères and Hope Estate with a Contribution to the "La Hueca Problem", edited by Corinne L. Hofman, and Menno L. P. Hoogland, 111-125. Leiden: Faculty of Archaeology, Archaeological Studies Leiden University.

Pagán-Jiménez, Jaime R., Reniel Rodríguez-Ramos, Basil A. Reid, Martijn van den Bel, and Corinne L. Hofman. 2015. "Early Dispersals of Maize and Other Food Plants into the Southern Caribbean and Northeastern South America." Quaternary Science Reviews 123: 231-246.

Petersen, James B. 1996. "Archaeology of Trants, Montserrat. Part 3. Chronological and Settlement Data." Annals of Carnegie Museum 65 (4): 323-361.

Pregill, Gregory K., David W. Steadman, and David R. Watters. 1994. "Late Quaternary Vertebrate Faunas of the Lesser Antilles: Historical Components of Caribbean Biogeography." Bulletin of Carnegie Museum of Natural History 30: 51.

Rodríguez Ramos, Reniel, Elvis Babilonia, L. Antonio Curet, and Jorge Ulloa. 2008. "The Pre-Arawak Pottery Horizon in the Antilles: A New Approximation." Latin American Antiquity 19 (1): 47-63.

Rodríguez Ramos, Reniel, Jaime R. Pagán Jiménez, and Corine L. Hofman. 2013. "The Humanization of the Insular Caribbean." In The Oxford Handbook of Caribbean Archaeology, edited by William F. Keegan, Corine L. Hofman, and Reniel Rodríguez Ramos, 126140. New York: Oxford University Press.

Romon, Thomas, Pascal Bertran, Axel Daussy, Pierrick Fouéré, Christine Fouilloud, Sandrine Grouard, Mathieu 
Hildebrand, Nathalie Serrand, and Christian Valet. 2006. Le Site de la Gare Maritime de Basse-Terre, Guadeloupe. Rapport d'opération de Fouille archéologique préventive, Inrap Grand-Sud-Ouest, Service Régional d'Archéologie de Guadeloupe, Basse-Terre, 455 p.

Romon, Thomas, Pascal Bertran, Pierrick Fouéré, Mathieu Hildebrand, and Nathalie Serrand. 2013. "Le Site de la Gare Maritime de Basse-Terre (Guadeloupe)." In Martinique, Terre Amérindienne: Une approche pluridisciplinaire, Séminaire international, Association Ouacabou, EA929 Univ. Antilles-Guyane, Conseil Général, DRAC 8-9 mai 2007, Fort-de-France, edited by Benoît Bérard, 223-234. Leiden: Sidestone Press.

Romon, Thomas, Pascal Bertran, and Nathalie Serrand. 2008. Saint-Martin, Etang Rouge, Lot 411 (Guadeloupe). Rapport d'opération de Fouille archéologique préventive, Inrap Grand-Sud-Ouest, Service Régional d'Archéologie de Guadeloupe, Basse-Terre, 156 p.

Rouse, Irving B. 1992. The Taïnos: Rise and Decline of the People Who Greeted Colombus. New Haven, London: Yale University Press. 211 p.

Samuelian, Clara, Dominique Bonnissent, Sandrine Grouard, Christophe Jorda, Nathalie Sellier-Segard, and Nathalie Serrand. 2016. COM, Saint-Martin, GrandCase, Rue des Flamboyants. Rapport d'opération de Fouille archéologique préventive, Inrap Grand-SudOuest, Service Régional d'Archéologie de Guadeloupe, Basse-Terre, $334 \mathrm{p}$.

Sellier-Segard, Nathalie, and Clara Samuelian. in press. "Un Village de Bord de Mer du Néoindien Récent à GrandCase (Saint-Martin, Petites Antilles)." Paper presented at the 26th Congress of the International Association for Caribbena Archaeology, Saint-Martin, French Lesser Antilles, July 19-24, 2015.

Serrand, Nathalie. 2002. "Exploitation des Invertébrés Marins et Terrestres par les Populations Saladoïdes et Post- Saladoïdes du Nord des Petites Antilles (500 B.C.1200 A.D.). Étude de cas et comparaisons." PhD diss., Université Paris I Panthéon-Sorbonne, PréhistoireEthnologie-Anthropologie, Paris.

Serrand, Nathalie. 2004. "Les Restes de Mollusques et de Crustacés de l'Occupation Amérindienne de la Cathédrale de Basse-terre." In Le site de la Cathédrale de Basse-Terre, Guadeloupe, edited by D. Bonnissent, 4560. Pessac: INRAP. Rapport d'opération de Fouille archéologique préventive, Inrap Grand-Sud-Ouest, Service Régional d'Archéologie de Guadeloupe, BasseTerre.

Serrand, Nathalie. 2005a. "Exploitation des Mollusques et Crustacés sur le Site Précéramique d'Etang Rouge 1, Saint-Martin, Guadeloupe.” In Cultures précolombiennes des Petites Antilles. Les occupations précéramiques de l'Etang Rouge 1. Baie Rouge, Les Terres Basses, Ile de StMartin, Région Guadeloupe, edited by D. Bonnissent, 106-132. Pessac: INRAP. Rapport d'opération de Fouille archéologique préventive, Inrap Grand-Sud-Ouest, Service Régional d'Archéologie de Guadeloupe, BasseTerre.

Serrand, Nathalie. 2005b. "Les Restes de Mollusques du Site saladoïde Moyen-Tardif du Diamant à Dizac, Martinique (450-700 apr. J.-C.): Une Exploitation entre Mer et Mangrove. Résultats préliminaires." In Proceedings of the 20th international Congress of the Association for Caribbean archaeology, République Dominicaine 2003, edited by Glenis Tavárez María, and Manuel A. García Arévalo. Santo Domingo: International Association for
Caribbean Archaeology, Museo del Hombre Dominicano, Fundación García Arévalo, 159-168.

Serrand, Nathalie. 2006. "La Malacofaune." In Le site de la Gare Maritime de Basse-Terre, Guadeloupe, edited by Thomas Romon, 126-184. Pessac: INRAP. Rapport d'opération de Fouille archéologique préventive, Inrap Grand-Sud-Ouest, Service Régional d'Archéologie de Guadeloupe, Basse-Terre.

Serrand, Nathalie. 2007a. “L’Economie des Sociétés Précolombiennes des Petites Antilles. Contribution des Données sur l'Exploitation des Invertébrés Marins et Terrestres." In Archéologie des départements français d'Amérique, directed by Stephen Rostain, and Nathalie Vidal, Les Nouvelles de l'Archéologie 108-109, 78-90.

Serrand, Nathalie. 2007b. “L'Exploitation des Invertébrés durant l'Occupation Céramique tardive du Sud de la Martinique: Aperçu Diachronique au travers des Sites de Dizac, Salines, Trabaud et Macabou." In Proceedings of the 21st International Congress of the Association for Caribbean archaeology, Trinidad 2005, edited by B. Reid, H. Petitjean Roget and A Curet. SaintAugustine, Trinidad: International Association for Caribbean Archaeology, University of the West Indies, School of Continuing Studies, 421-428.

Serrand, Nathalie. 2008. "II.3 Etude Faunique." In SaintMartin, Etang Rouge3, lot 411, Guadeloupe, edited by Thomas Romon, Pascal Bertran, and Nathalie Serrand, 57-114. Pessac: INRAP. Rapport d'opération de Fouille archéologique préventive, Inrap Grand-Sud-Ouest, Service Régional d'Archéologie de Guadeloupe, BasseTerre.

Serrand, Nathalie. 2013a. "Les Restes d'Invertébrés Marins des Dépôts Précéramiques." In Les gisements précolombiens de la Baie Orientale: campements $d u$ Mésoindien et $d u$ Néoindien sur l'île de Saint-Martin (Petites Antilles), directed by Dominique Bonnissent. Paris : Éditions de la Maison des sciences de l'homme, 2013. (Documents d'archéologie française 107), 53-90.

Serrand, Nathalie. 2013b. "Les Restes d'Invertébrés Marins des Dépôts post-Saladoïdes." In Les gisements précolombiens de la Baie Orientale: campements $d u$ Mésoindien et $d u$ Néoindien sur l'île de Saint-Martin (Petites Antilles), directed by Dominique Bonnissent. Paris : Éditions de la Maison des sciences de l'homme, 2013. (Documents d'archéologie française 107), 212-218. Serrand, Nathalie. 2016. "L'Etude des Restes d'Invertébrés Marins." In COM, Saint-Martin, Grand-Case, Rue des Flamboyants, edited by Clara Samuelian, 127-149. Pessac: INRAP. Rapport d'opération de Fouille archéologique préventive, Inrap Grand-Sud-Ouest, Service Régional d'Archéologie de Guadeloupe, Basse-Terre.

Serrand, Nathalie, Pascal Bertran, Dominique Bonnissent, Fabrice Casagrande, Anne Dietrich, Sandrine Grouard, Sibilla Orsini, Erika Ribechini, T. Romon, and Nathalie Sellier-Segard. 2016. Guadeloupe, Capesterre-de-MarieGalante, Stade José Bade : Les Occupations Cedrosansaladoïde et Troumassan-troumassoïde de Tourlourous. Rapport d'opération de Fouille archéologique préventive, Inrap Grand-Sud-Ouest, Service Régional d'Archéologie de Guadeloupe, Basse-Terre, 836 p.

Siegel, Peter E. 1991. "Migration Research in Saladoid Archaeology: A Review." The Florida Anthropologist 44 (1): 79-91.

Stouvenot, Christian, and Auran Randrianasolo. 2006. “L'Origine des Matières Premières Lithiques 
Précéramiques." In Les Gisements Précolombiens de la Baie Orientale : Campements $d u$ Mésoindien et $d u$ Néoindien sur l'Ile de Saint-Martin (Petites Antilles), directed by Dominique Bonnissent, Paris : Éditions de la Maison des Sciences de l'Homme, Documents d'archéologie française 107, 129-136.

Tedesco, K., and R. Thunell. 2003. "High Resolution Tropical Climate Record for the Last 6,000 Years." Geophysical Research Letters 30 (17): 1891.

Vidal, Nathalie. 1999. "Le Site Précolombien de la Plage Dizac au Diamant, Martinique." In Proceedings of the 16th International Congress of the Association for Caribbean archaeology, Guadeloupe 1995, Conseil Régional de la Guadeloupe, Mission Archéologique et du Patrimoine, Basse-Terre, Guadeloupe, 7-16.

Watters, David R. 1980. "Transect Surveying and prehistoric Site Locations on Barbuda and Montserrat, Leeward Islands, West Indies". PhD diss., Dept of Anthropology, University of Pittsburgh, University Microfilms, Ann Arbor, $416 \mathrm{p}$.

Watters, David R., J. Donahue, and R. Stuckenrath. 1992. "Palaeoshorelines and the Prehistory of Barbuda, West Indies." In Palaeoshorelines and Prehistory. An
Investigation of Method, edited by L. L. Johnson, 15-52. Florida: C.R.C. Press.

Watters, David R., and James B. Petersen. 1993. "Preliminary Report on the Archaeology of the Rendezvous Bay Site, Anguilla." In Proceedings of the 14th International Congress for Caribbean Archaeology, Barbados 1991, edited by Alissandra Cummins, and P. King. St. Ann's Garrison, Barbados: Barbados Museum and Historical Society, 25-33.

Watters, David R., and James B. Petersen. 1999. "Trants, Montserrat: the 1995 Field Season.” In Proceedings of the 16th International Congress for Caribbean Archaeology. Basse-Terre, Guadeloupe 1995. BasseTerre, Guadeloupe: Conseil Régional Guadeloupe, Mission Archéologique et du Patrimoine, 27-39.

Wilson, Samuel. M. 1989. "The prehistoric Settlement Pattern of Nevis, West Indies." Journal of Field Archaeology 16 (4): 427-450.

Woodruff, Jonathan D., Jeffrey P. Donnelly, David Mohrig, and Wayne R. Geyer. 2008. "Reconstructing Relative Flooding Intensities Responsible for Hurricane-Induced Deposits from Laguna Playa Grande, Vieques, Puerto Rico." Geology 36: 391-394. 